\title{
Renal Excretion of Water in Infants with Acute Gastroenteritis
}

\author{
JOHN PATRICK* \\ From St. George's Hospital, London
}

\begin{abstract}
Patrick, J. (1971). Archives of Disease in Childhood, 46, 641. Renal excretion of water in infants with acute gastroenteritis. Infants with severe gastroenteritis were given water loads of $20 \mathrm{ml} / \mathrm{kg}$ body weight during their recovery. The renal responses were correlated with changes in body weight and osmolality. A water load was not excreted until the body weight had reached a peak. It is concluded that while volume depletion persists administration of hypotonic fluids leads to a fall in osmolality which will not be corrected by renal excretion of water. The relevance of this observation to the high incidence of neurological disturbances during the treatment of hyperosmolar states is discussed.
\end{abstract}

Diarrhoeal fluid in gastroenteritis has a lower concentration of sodium than extracellular fluid (Finberg, Cheung, and Fleishman, 1960; Weil and Wallace, 1956; Darrow et al., 1949; Holt, Courtney, and Fales, 1915). In the absence of sufficient and appropriate intake hypernatraemia of the extracellular fluid will result. Severe neurological complications have been associated with hypernatraemia. Dural sinus thrombosis and cerebral petechial haemorrhages have been observed in necropsy material (Finberg, Kiley, and Luttrell, 1963), and in non-fatal cases subsequent mental defect has been noted (Macaulay and Watson, 1967; Morris-Jones, Houston, and Evans, 1967). The correct therapy for hypernatraemia in this situation is not definitely established. It is known

Received 29 March 1971.

^Present address: The Renal Unit, St. Thomas's Hospital, London S.E.1. that when hypernatraemia is associated with contraction of the body fluid volume the kidney's ability to correct the hypernatraemia is impaired (Finberg, Rush, and Cheung, 1964). It has also been shown that treatment with electrolyte-free solutions is associated with a higher incidence of convulsions than treatment with electrolyte-containing solutions (Bruck, Abal, and Aceto, 1968). Animal experiments suggest that the convulsions may be caused by cerebral oedema with rapid uptake of water by the brain. The data presented here are concerned with the changing response to a water load during recovery from severe gastroenteritis.

\section{Patients and Methods}

Eight infants with acute severe gastroenteritis were studied. Age, weight, surface area, and initial blood chemistry for each infant are shown in Table I. All the infants presented with severe salt and water defi-

TABLE I

Biochemical and Physical Details of Patients Studied

\begin{tabular}{|c|c|c|c|c|c|c|c|c|}
\hline $\begin{array}{l}\text { Case } \\
\text { No. }\end{array}$ & $\begin{array}{c}\text { Age } \\
\text { (mth) }\end{array}$ & $\begin{array}{l}\text { Wt. } \\
(\mathbf{k g})\end{array}$ & $\begin{array}{l}\text { BSA } \\
\left(\mathbf{m}^{2}\right)\end{array}$ & $\underset{(\mathrm{mEq} / \mathrm{l} .)}{\mathrm{Na}}$ & $\underset{(\mathrm{mEq} / \mathrm{l} .)}{\mathbf{K}}(\mathrm{ml})$ & $\begin{array}{c}\text { Urea } \\
(\mathrm{mg} / 100 \mathrm{ml})\end{array}$ & $\underset{(\mathrm{mg} / 100 \mathrm{ml})}{\text { Creatinine }}$ & $\begin{array}{c}\text { POsm } \\
(\mathrm{mOsm} / \mathrm{kg})\end{array}$ \\
\hline $\begin{array}{l}1 \\
2\end{array}$ & $\begin{array}{l}10 \\
14\end{array}$ & $\begin{array}{c}9 \cdot 6 \\
10 \cdot 25\end{array}$ & $\begin{array}{l}0.42 \\
0.43\end{array}$ & $\begin{array}{l}155 \\
157\end{array}$ & $\begin{array}{l}3 \cdot 3 \\
3 \cdot 2\end{array}$ & $\begin{array}{r}114 \\
95\end{array}$ & $\begin{array}{c}1 \cdot 3 \\
1 \cdot 0 \\
(7 \mathrm{hr})\end{array}$ & $\begin{array}{l}346 \\
346\end{array}$ \\
\hline $\begin{array}{l}3 \\
4 \\
5 \\
6 \\
7 \\
7 \\
8\end{array}$ & $\begin{array}{r}2 \\
21 \\
8 \\
7 \\
10 \\
6\end{array}$ & $\begin{array}{c}5 \cdot 25 \\
10 \cdot 8 \\
7 \cdot 7 \\
8 \cdot 7 \\
7 \cdot 35 \\
7 \cdot 9\end{array}$ & $\begin{array}{l}0.265 \\
0.48 \\
0.36 \\
0.38 \\
0.344 \\
0.42\end{array}$ & $\begin{array}{r}151 \\
142 \\
148 \\
152 \\
140\end{array}$ & $\begin{array}{l}7 \cdot 0 \\
2 \cdot 6 \\
4 \cdot 8 \\
3 \cdot 8 \\
4 \cdot 7 \\
4 \cdot 8\end{array}$ & $\begin{array}{r}128 \\
32 \\
160 \\
80 \\
29 \\
-\end{array}$ & $\begin{array}{l}2.1 \\
0.5 \\
1.5 \\
0.9 \\
0.9 \\
0.9\end{array}$ & $\begin{array}{l}350 \\
315 \\
324 \\
320 \\
305 \\
300\end{array}$ \\
\hline
\end{tabular}

Note: The weights are the final weights before discharge.

The blood chemistry results are on admission, unless the time is shown in parentheses.

BSA $=$ Body surface area. 
ciency: grades 2 or 3 of the M.R.C. criteria (Medical saline, plasma, or dextran). Repletion of the overall Research Council Memorandum No. 26, 1952). Treatment was designed to correct peripheral circulatory failure rapidly with intravenous isotonic fluids $(0.9 \%$

deficit was attempted in 24-36 hours with $\frac{1}{2}$ or $\frac{1}{1}$ strength

Darrow's solution ( $\frac{1}{2}$ strength Darrow's solution-

sodium $60 \mathrm{mEq} / \mathrm{l}$, potassium $18.1 \mathrm{mEq} / \mathrm{l}$, chloride

TABLE II

Data Showing Relations Between Changes in Osmolality, Weight, and Renal Function

\begin{tabular}{|c|c|c|c|c|c|c|c|c|c|}
\hline $\begin{array}{l}\text { Case } \\
\text { No. }\end{array}$ & $\begin{array}{c}\text { Time } \\
\text { (hr) } \\
\text { from } \\
\text { Admission }\end{array}$ & $\begin{array}{l}\text { W/t. } \\
\text { (kg) }\end{array}$ & $\underset{(\mathrm{mOsm} / \mathrm{kg})}{\text { POsm }}$ & $\underset{(\mathrm{ml} / \mathrm{min})}{\mathrm{V}}$ & $\underset{(\mathrm{mOsm} / \mathrm{kg})}{\text { UOsm }}$ & $\underset{(\mathrm{ml} / \mathrm{min})}{\mathrm{CH}_{2} \mathrm{O}}$ & $\underset{(\mu \mathrm{Eq} / \mathrm{min})}{\mathrm{UNaV}}$ & $\underset{(\mathrm{ml} / \mathrm{min})}{\mathrm{CCr}}$ & $\begin{array}{l}\% \text { Water } \\
\text { Load } \\
\text { Excreted } \\
\text { in } 5 \mathbf{h r}\end{array}$ \\
\hline 1 & $\begin{array}{l}0 \cdot 0 \\
15 \cdot 0 \\
19 \cdot 15 \\
24 \cdot 0-24 \cdot 3 \\
25 \cdot 30\end{array}$ & $\begin{array}{c}8.75 \\
9.55 \\
9 \cdot 57 \\
\text { water load o } \\
9.65\end{array}$ & $\begin{array}{r}346 \\
299 \\
297 \\
\mathrm{f} 300 \mathrm{ml} \\
\end{array}$ & $\begin{array}{l}0 \cdot 14 \\
0 \cdot 2 \\
0 \cdot 1\end{array}$ & $\begin{array}{l}800 \\
861 \\
776\end{array}$ & $\begin{array}{l}-0.26 \\
-0.35 \\
-1 \cdot 2\end{array}$ & $\begin{array}{l}2 \cdot 6 \\
6 \cdot 0 \\
4 \cdot 4\end{array}$ & $\begin{array}{r}10 \cdot 3 \\
19 \cdot 0 \\
8 \cdot 0\end{array}$ & $2 \cdot 3$ \\
\hline 2 & $\begin{array}{l}0 \cdot 0 \\
10 \cdot 13 \\
11 \cdot 30-12 . \\
13 \cdot 38 \\
15 \cdot 31 \\
20 \cdot 46 \\
23 \cdot 55\end{array}$ & $\begin{array}{c}7 \cdot 2 \\
7 \cdot 68 \\
5 \text { water load } \\
8 \cdot 83 \\
9 \cdot 4 \\
9 \cdot 6 \\
10 \cdot 0\end{array}$ & $\begin{array}{r}350 \\
321 \\
\text { of } 250 \mathrm{ml} \\
317 \\
= \\
=\end{array}$ & $\begin{array}{l}0.4 \\
\\
0.3 \\
0.4 \\
0.3 \\
0.4\end{array}$ & $\begin{array}{l}570 \\
283 \\
346 \\
349 \\
332\end{array}$ & $\begin{array}{c}-0.3 \\
0.0 \\
-0.02 \\
-0.02 \\
0.0\end{array}$ & $\begin{array}{l}26 \cdot 6 \\
11 \cdot 6 \\
23 \cdot 8 \\
21 \cdot 1 \\
23 \cdot 1\end{array}$ & $\begin{array}{r}7 \cdot 0 \\
4 \cdot 0 \\
8 \cdot 0 \\
9 \cdot 0 \\
10 \cdot 5\end{array}$ & $23 \cdot 2$ \\
\hline 3 & $\begin{array}{l}0 \cdot 0 \\
7 \cdot 5 \\
10 \cdot 10 \\
15 \cdot 45 \\
20 \cdot 15 \\
20 \cdot 15-21 . \\
23 \cdot 0\end{array}$ & $\begin{array}{c}4 \cdot 66 \\
4 \cdot 86 \\
4 \cdot 92 \\
4 \cdot 98 \\
5 \cdot 0 \\
\text { water load } \\
5 \cdot 1\end{array}$ & 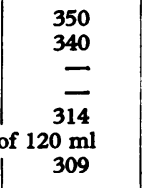 & $\begin{array}{l}0 \cdot 1 \\
0 \cdot 18 \\
0 \cdot 11 \\
0 \cdot 15\end{array}$ & $\begin{array}{r}527 \\
693 \\
801 \\
1000 \\
\\
\text { Next u }\end{array}$ & $\begin{array}{r}-0.05 \\
-0.19 \\
-0.26 \\
-0.33 \\
10 \mathrm{hr} \text { afte }\end{array}$ & $\begin{array}{r}3 \cdot 5 \\
8 \cdot 9 \\
6 \cdot 4 \\
7 \cdot 2 \\
\end{array}$ & $\begin{array}{l}3 \cdot 2 \\
8 \cdot 1 \\
4 \cdot 6 \\
7 \cdot 2\end{array}$ & $\theta .0$ \\
\hline 4 & $\begin{array}{l}0 \cdot 0 \\
11 \cdot 45 \\
15 \cdot 00 \\
19 \cdot 00 \\
19 \cdot 30-20 . \\
22 \cdot 22\end{array}$ & $\begin{array}{l}10 \cdot 2 \\
10 \cdot 75 \\
10.9 \\
11 \cdot 0 \\
\text { water load } \\
10.95\end{array}$ & $\begin{array}{r}315 \\
293 \\
\\
293 \\
\text { of } 300 \mathrm{ml} \\
291\end{array}$ & $\begin{array}{l}0.2 \\
0.55 \\
\\
0.71\end{array}$ & $\begin{array}{r}646 \\
425 \\
\\
213\end{array}$ & $\begin{array}{l}-0.2 \\
-0.25 \\
+0.2\end{array}$ & $\begin{array}{r}7 \cdot 5 \\
41 \cdot 8 \\
\\
35 \cdot 9\end{array}$ & $\begin{array}{r}24 \cdot 3 \\
34 \cdot 0 \\
\\
11 \cdot 2\end{array}$ & $75 \cdot 0$ \\
\hline 5 & $\begin{array}{l}0 \cdot 0 \\
12 \cdot 0 \\
15 \cdot 30 \\
16 \cdot 40-17 \\
16 \cdot 55 \\
18 \cdot 00 \\
23 \cdot 30\end{array}$ & $\begin{array}{c}7 \cdot 3 \\
7 \cdot 8 \\
7 \cdot 72 \\
\text { water load } \\
\overline{-} \\
7 \cdot 65\end{array}$ & $\begin{array}{l}324 \\
\text { of } 215 \mathrm{ml} \\
300\end{array}$ & $\begin{array}{l}0.02 \\
0.07 \\
\\
0.5 \\
1.54\end{array}$ & $\begin{array}{l}524 \\
515 \\
\\
\\
212 \\
494\end{array}$ & $\begin{array}{l}-0.02 \\
-0.05 \\
\\
+0.2 \\
+2.1\end{array}$ & $\begin{array}{r}0.3 \\
0.8 \\
\\
6 \cdot 2 \\
17 \cdot 0\end{array}$ & $\begin{array}{r}1 \cdot 8 \\
3 \cdot 0 \\
\\
\\
6 \cdot 3 \\
13 \cdot 4\end{array}$ & $55 \cdot 0$ \\
\hline 6 & $\begin{array}{l}0 \cdot 0 \\
12 \cdot 30 \\
16 \cdot 45 \\
21 \cdot 25 \\
22 \cdot 00-22 \\
23 \cdot 35 \\
24 \cdot 03\end{array}$ & $\begin{array}{c}8 \cdot 08 \\
8 \cdot 7 \\
8 \cdot 94 \\
8 \cdot 85 \\
\text { water load } \\
8 \cdot 8\end{array}$ & $\begin{array}{r}320 \\
297 \\
\\
290 \\
\text { of } 230 \mathrm{ml}\end{array}$ & $\begin{array}{l}0 \cdot 07 \\
0 \cdot 3 \\
0 \cdot 29 \\
1 \cdot 43 \\
2 \cdot 2\end{array}$ & $\begin{array}{r}1063 \\
646 \\
465 \\
\\
218 \\
82\end{array}$ & $\begin{array}{l}-1.4 \\
-0.4 \\
-0.2 \\
+0.4 \\
+1.9\end{array}$ & $\begin{array}{r}0 \cdot 4 \\
2 \cdot 3 \\
16 \cdot 7 \\
\\
47 \cdot 7 \\
47 \cdot 3\end{array}$ & $\begin{array}{r}4 \cdot 0 \\
11 \cdot 2 \\
12 \cdot 8 \\
\\
21 \cdot 5 \\
21 \cdot 7\end{array}$ & $100 \cdot 0$ \\
\hline 7 & $\begin{array}{l}0 \cdot 0 \\
3 \cdot 25 \\
5 \cdot 35 \\
21 \cdot 55 \\
23 \cdot 25 \\
23 \cdot 45-24 \cdot \\
26 \cdot 3\end{array}$ & $\begin{array}{c}6 \cdot 83 \\
7 \cdot 0 \\
7 \cdot 23 \\
7 \cdot 34 \\
7 \cdot 3 \\
\text { water load } \\
7 \cdot 29\end{array}$ & 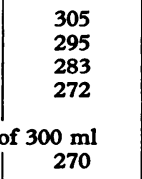 & $\begin{array}{l}0.09 \\
0.1 \\
0.06 \\
0.04 \\
1.55\end{array}$ & $\begin{array}{l}886 \\
866 \\
863 \\
742 \\
69\end{array}$ & $\begin{array}{l}-0.18 \\
-0.2 \\
-0.13 \\
-0.07 \\
+1.16\end{array}$ & $\begin{array}{r}11 \cdot 5 \\
18 \cdot 0 \\
7 \cdot 5 \\
11 \cdot 6 \\
21 \cdot 8\end{array}$ & $\begin{array}{r}7 \cdot 9 \\
8 \cdot 2 \\
3 \cdot 5 \\
3 \cdot 9 \\
15 \cdot 6\end{array}$ & $\begin{array}{l}46 \cdot 0 \\
\text { in } 2 \frac{1}{2} \mathrm{hr}\end{array}$ \\
\hline 8 & $\begin{array}{l}0 \cdot 0 \\
6 \cdot 30 \\
9 \cdot 30 \\
12 \cdot 00 \\
14 \cdot 25 \\
14 \cdot 15-14 \cdot \\
16 \cdot 26 \\
17 \cdot 21 \\
19 \cdot 58 \\
22 \cdot 30\end{array}$ & \begin{tabular}{|l}
$7 \cdot 14$ \\
$7 \cdot 75$ \\
$7 \cdot 94$ \\
\\
water load \\
$7 \cdot 9$ \\
$7 \cdot 9$
\end{tabular} & \begin{tabular}{|r}
300 \\
284 \\
\\
of $240 \mathrm{ml}$ \\
270
\end{tabular} & $\begin{array}{l}0 \cdot 04 \\
0 \cdot 2 \\
0 \cdot 21 \\
0 \cdot 18 \\
1 \cdot 0 \\
2 \cdot 1 \\
0 \cdot 28 \\
0 \cdot 26\end{array}$ & $\begin{array}{r}623 \\
558 \\
547 \\
451 \\
\\
329 \\
70 \\
296 \\
538\end{array}$ & $\begin{array}{l}-0.05 \\
-0.18 \\
-0.19 \\
-0.11 \\
-0.22 \\
+1.55 \\
+0.03 \\
-0.26\end{array}$ & $\begin{array}{c}0 \cdot 46 \\
4 \cdot 0 \\
11 \cdot 8 \\
9 \cdot 8 \\
18 \cdot 4 \\
17 \cdot 0 \\
9 \cdot 4 \\
18 \cdot 7\end{array}$ & $\begin{array}{r}4 \cdot 7 \\
13.5 \\
12 \cdot 6 \\
9 \cdot 5 \\
17 \cdot 6 \\
16 \cdot 7 \\
9 \cdot 0 \\
18 \cdot 5\end{array}$ & $79 \cdot 0$ \\
\hline
\end{tabular}


$52.5 \mathrm{mEq} / 1$, and lactate $26 \mathrm{mEq} / 1$.) administered orally. The deficit was estimated clinically using the M.R.C. criteria. Approximately $150 \mathrm{ml}$ water $/ \mathrm{kg}$ per 24 hours were allowed for maintenance requirements. A high maintenance figure is required because of the high insensible water loss secondary to acidosis and fever (Kerrigan, 1963; Heeley and Talbot, 1955).

The response to an oral water load of 2 to $3 \%$ body weight given over 30 minutes, and additional to the normal fluid therapy, was studied at varying times during recovery. The infants were weighed frequently so that 5 to 9 measurements were obtained in the first 24 hours after admission. Weighings were accurate to 10-15 g.

Urine was collected in carefully timed periods with spontaneous voidings, catheterization being considered unethical. Plasma and urinary sodium, potassium, creatinine, and osmolality were measured. From these data creatinine, osmolal, and free water clearance were calculated as follows: $\mathrm{C} . \mathrm{Cr}$, creatinine clearance =

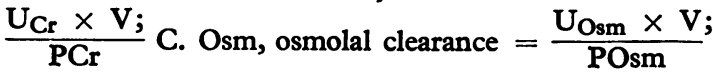
$\mathrm{CH}_{2} \mathrm{O}$, free water clearance $=\mathrm{V}-\mathrm{CO}$ sm.

Where $U_{\mathrm{cr}}=$ urinary creatinine concentration $\mathrm{mg} /$ $100 \mathrm{ml} ; \mathrm{U}_{\mathrm{osm}}=$ urinary osmolality $\mathrm{mOsm} / \mathrm{kg} ; \mathrm{P}_{\mathrm{cr}}=$ plasma creatinine $\mathrm{mg} / 100 \mathrm{ml} ; \mathrm{P}_{\mathrm{osm}}=$ plasma osmolality $\mathrm{mOsm} / \mathrm{kg}$; and $\mathrm{V}=$ urine flow $\mathrm{ml} / \mathrm{min}$.

Free water clearance was used as the index of renal ability to excrete a water load. It represents the rate at which the kidneys remove 'pure' (i.e. solute-free) water from the plasma. Sodium and potassium were estimated by flame photometry, osmolality by freezing point depression with an 'advanced' osmometer, and creatinine by the Technicon modification of the Folin and Wu method.

All clearances are expressed as means of two or three consecutive periods.

\section{Results}

Plasma osmolality was initially high in all the infants though not all were hypernatraemic. At the time of the water load, 4 infants were still hyperosmolar. Weight changes in all the infants followed a similar pattern, with an initial rapid gain followed by a peak or plateau before normal growth was resumed.

It was found that when the water load was given after the peak weight during recovery there was an appropriate rise in urine flow and free water clearance with a sharp fall in urinary osmolality. However, when the water load was given before the peak weight had been reached the renal response was minimal or absent (Table II, Fig. 1-3). Sodium excretion rose and creatinine clearance increased in association with water loading after the peak weight had been reached.

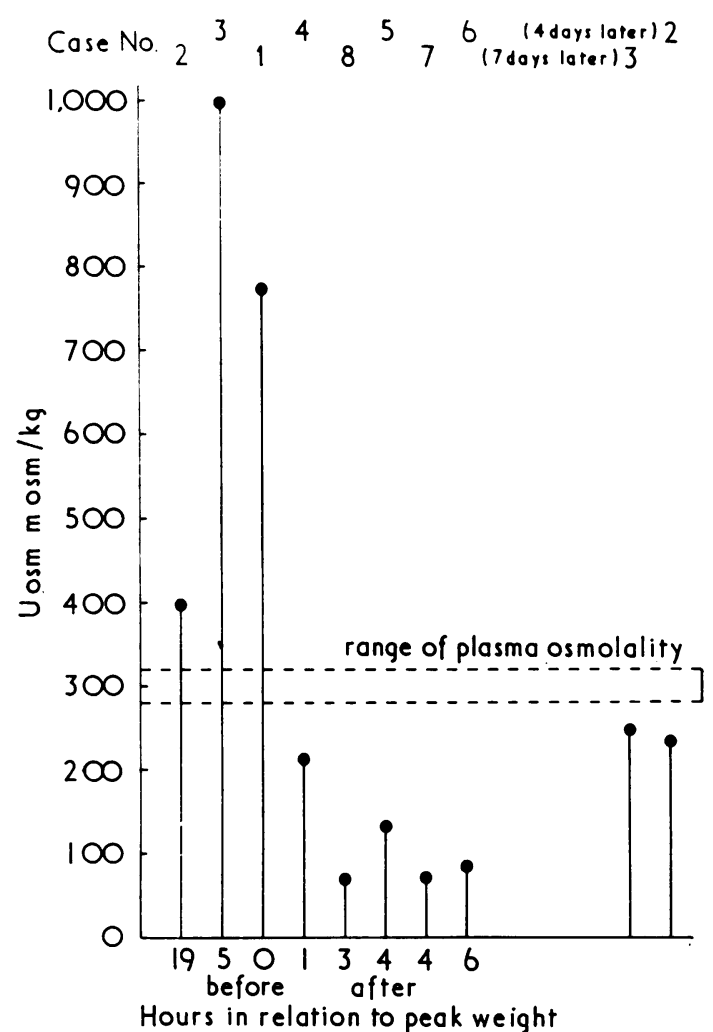

FIG. 1.-Plot of lowest $\mathrm{U}_{\mathrm{Osm}}$ achieved after $\mathrm{H}_{2} \mathrm{O}$ load against time relative to peak weight.

\section{Discussion}

It has been shown that when infants with gastroenteritis and hypernatraemia are treated with electrolyte-free solutions there is a high incidence of convulsions (Bruck et al., 1968). The present results show that these infants retain all administered water for several hours after the beginning of fluid therapy. If fluid therapy is very hypotonic this will cause retention of water with dilution of the body fluids. Studies of experimental animals in comparable states have shown an increase in brain water leading to neurological disturbances and ultimately to death (Hogan et al., 1969). It seems likely that the convulsions occurring during treatment of children with gastroenteritis with hypotonic solutions are also related to water retention, and an understanding of the changes in renal water excretion at this time is therefore important.

During fluid therapy the weight change of these children followed a characteristic pattern, rising steeply to a peak then falling slightly before rising again more slowly. A normal renal response to a 


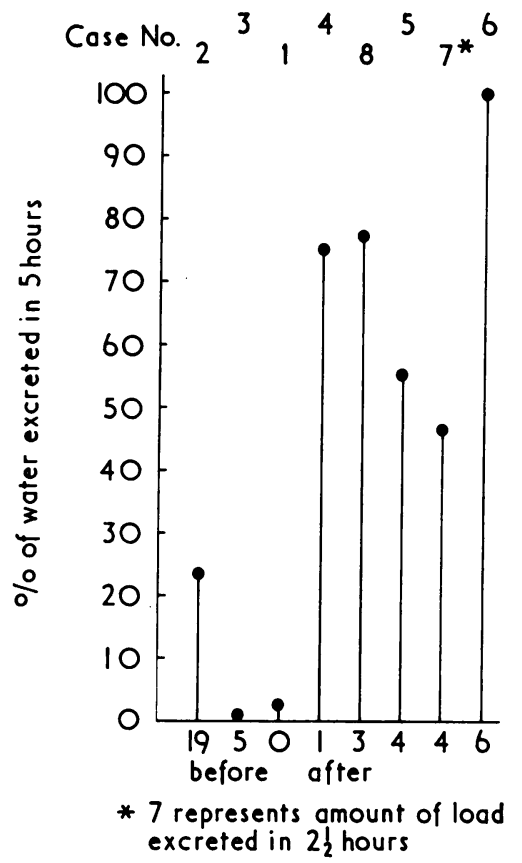

Fig. 2.-Plot of percentage of water load excreted against time relative to peak weight.

water load was not seen before the first peak in body weight, but water loads given after the peak were excreted more normally. This pattern of weight change corresponds with the initial salt retention in excess of salt deficit observed by Darrow (Darrow, 1946). The drop in weight corresponds with the excretion of the excess sodium. Natriuresis does not follow a water load (Metzger et al., 1969) but is a well-documented response to volume expansion. Similar over-retention of sodium has been reported in experimental salt depletion (McCance, 1936). It is also known that salt depletion impairs the renal response to a water load in the dog (Cizek and Huang, 1951; Coxon and Ramsay, 1968) and in man (McCance and Widdowson, 1937). The recovery of the renal ability to excrete a water load after the body weight peaked during treatment suggests that the initial defect in water excretion was related to the salt deficiency and consequent deficiency of extracellular volume.

Although salt deficiency thus appears to be a likely cause for the change in water excretion, other possible causes are present. Potassium depletion is also usually present in infants with gastroenteritis (Darrow et al., 1949), but the renal ability to form a dilute urine is well maintained in potas-

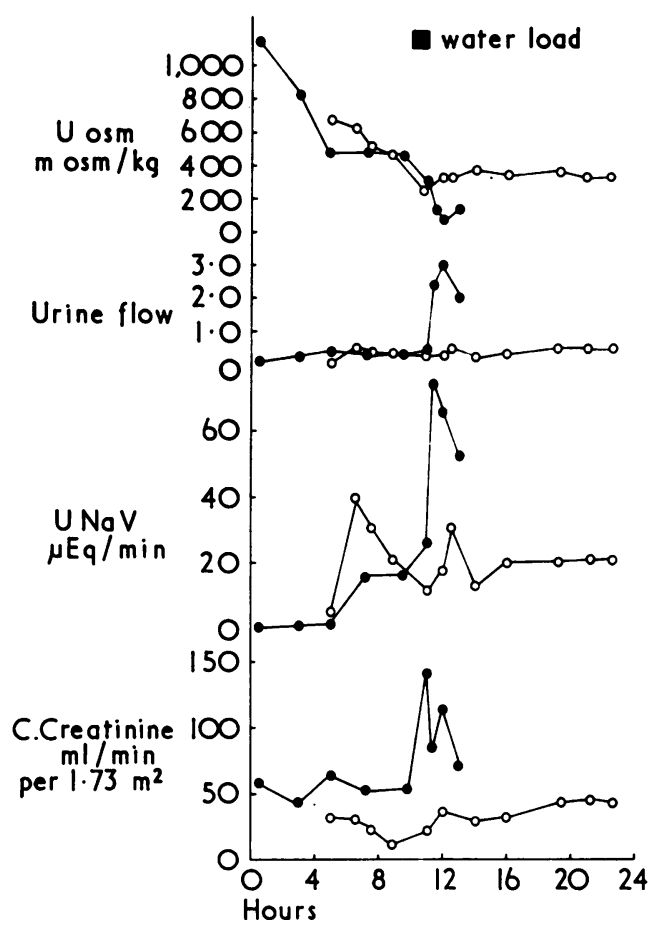

Fig. 3. Plot of changes in $U_{\text {Osm }}$ urine flow, sodium excretion, and creatinine clearance in relation to a water load. Open circles indicate a subject loaded before peak weight was reached. Closed circles indicate a subject loaded after peak weight was reached.

sium deficient animals and man until the deficit is large (Levitin, Manitius, and Epstein, 1960; Holliday et al., 1960; Rubini, 1961).

The fluid losses in gastroenteritis also lead to a fall in glomerular filtration rate (Calcagno and Rubin, 1951), and this may impair the response to a water load. The creatinine clearances in these infants must be interpreted with caution in view of the difficulties of accurate measurement. However, they suggest that the glomerular filtration rate was reduced initially and returned to normal only slowly. Physicians caring for such infants will be familiar with the tendency for the blood urea to remain high for several days after correction of the fluid deficit. This slow recovery of the glomerular filtration rate contrasts with the rapid recovery of the water excretory ability after peak weight and suggests that salt deficiency may impair the mechanism for urinary dilution independently of the glomerular filtration rate. Whatever the precise mechanism, the anomaly in water excretion present in infants with gastroenteritis must be appreciated 
when planning fluid replacement and underlines the dangers of rapidly administered hypotonic fluids in the presence of an extracellular volume deficit. In these circumstances dangerous dilutional hyponatraemia can develop very rapidly since the normal water diuretic response is inhibited. We were careful to avoid rapid administration of large quantities of hypotonic fluids while a deficiency of extracellular fluid was still present, and it is interesting that no neurological abnormalities or sequelae were seen in these children.

I thank the Board of Governors of St. George's Hospital and the Central Research Fund of the University of London for research grants; Mrs. Maitland and her staff for their help and encouragement; Dr. N. F. Jones for advice during the preparation of the manuscript; Dr. H. P. Lambert for his consistent help and encouragement; and Sisters S. Linton and S. J. Jones for their patient co-operation in this study.

\section{REFERENCES}

Bruck, E., Abal, G., and Aceto, T., Jr. (1968). Therapy of infants with hypertonic dehydration due to diarrhea. American Journal of Diseases of Children, 115, 281.

Calcagno, P. L., and Rubin, M. I. (1951). Effect of dehydration produced by water deprivation, diarrhea and vomiting on renal function. Pediatrics, $7,328$.

Cizek, L. J., and Huang, K. C. (1951). Water diuresis in the saltdepleted dog. American fournal of Physiology, 167, 473.

Coxon, R. V., and Ramsay, D. J. (1968). The effect of sodium depletion on the renal responses to water-loading in dogs. fournal of Physiology, 197, 617.

Darrow, D. C. (1946). The retention of electrolyte during recovery from severe dehydration due to diarrhea. Fournal of Pediatrics, $28,515$.

Darrow, D. C., Pratt, E. L., Flett, J., Jr., Gamble, A. H., and Wiese, H. F. (1949). Disturbances of water and electrolytes in infantile diarrhea. Pediatrics, 3, 129.

Finberg, L. Cheung, C. S., and Fleishman, E. (1960). The significance of the concentrations of electrolyte in stool water during infantile diarrhea. American fournal of Diseases of Children, $100,809$.
Finberg, L., Kiley, J., and Luttrell, C. N. (1963). Mass accidental salt poisoning in infancy. Fournal of the American Medical Association, 184, 187.

Finberg, L., Rush, B. F., Jr., and Cheung, C. S. (1964). Renal excretion of sodium during hypernatremia. American fournal of Diseases of Children, 107, 483.

Heeley, A. M., and Talbot, N. B. (1955). Insensible water losses per day by hospitalized infants and children. American fournal of Diseases of Children, 90, 251.

Hogan, G. R., Dodge, P. R., Gill, S. R., Master, S., and Sotos, J. F. (1969). Pathogenesis of seizures occurring during restoration of plasma tonicity to normal in animals previously chronically hypernatremic. Pediatrics, 43, 54.

Holliday, M. A., Segar, W. E., Bright, N., and Egan, T. (1960). The effect of potassium deficiency on the kidney. Pediatrics, 26, 950.

Holt, L. E., Courtney, A. M., and Fales, H. L. (1915). The chemical composition of diarrheal as compared with normal stools in infants. American fournal of Diseases of Children, 9, 213.

Kerrigan, G. A. (1963). Water and electrolyte metabolism in pediatrics. In Clinical Metabolism of Body Water and Electrolytes. Ed. by J. H. Bland. Saunders, Philadelphia.

Levitin, H., Manitius, A., and Epstein, F. H. (1960). Urinary dilution in potassium deficiency. Yale fournal of Biology and Medicine, 32, 390.

Macaulay, D., and Watson, M. (1967). Hypernatraemia in infants as a cause of brain damage. Archives of Disease in Childhood, 42, 485.

McCance, R. A. (1936). Experimental sodium chloride deficiency in man. Proceedings of the Royal Society. Series B. Biological Sciences, 119, 245.

McCance, R. A., and Widdowson, E. M. (1937). The secretion of urine in man during experimental salt deficiency. Fournal of Physiology, 91, 222.

Medical Research Council (1952). The treatment of acute dehydration in infants. Medical Research Council Memorandum, 26.

Metzger, R. A., Vaamonde, L. S., Vaamonde, C. A., and Papper, S. (1969). Renal excretion of sodium during oral water loading in man. Nephron, 6, 11.

Morris-Jones, P. H., Houston, I. B., and Evans, R. C. (1967) Prognosis of the neurological complications of acute hypernatraemia. Lancet, 2, 1385.

Rubini, M. E. (1961). Water excretion in potassium-deficient man fournal of Clinical Investigation, 40, 2215.

Weil, W. B., and Wallace, W. M. (1956). Hypertonic dehydration in infancy. Pediatrics, 17, 171.

Correspondence to Dr. J. Patrick, Medical Unit, St. Thomas's Hospital, London S.E.1. 